\title{
RISK FACTORS RELATED TO PESTICIDE EXPOSURE IN BANJAR HORTICULTURAL FARMERS
}

\author{
Dewa Ayu Eka Wahyuni, I Made Muliarta, Susy Purnawati \\ Udayana University, Indonesia \\ Email: ekawahyunii2202@gmail.com ${ }^{1}$, made_muliarta@unud.ac.id ${ }^{2}$, \\ s_purnawati@yahoo.com ${ }^{3}$
}

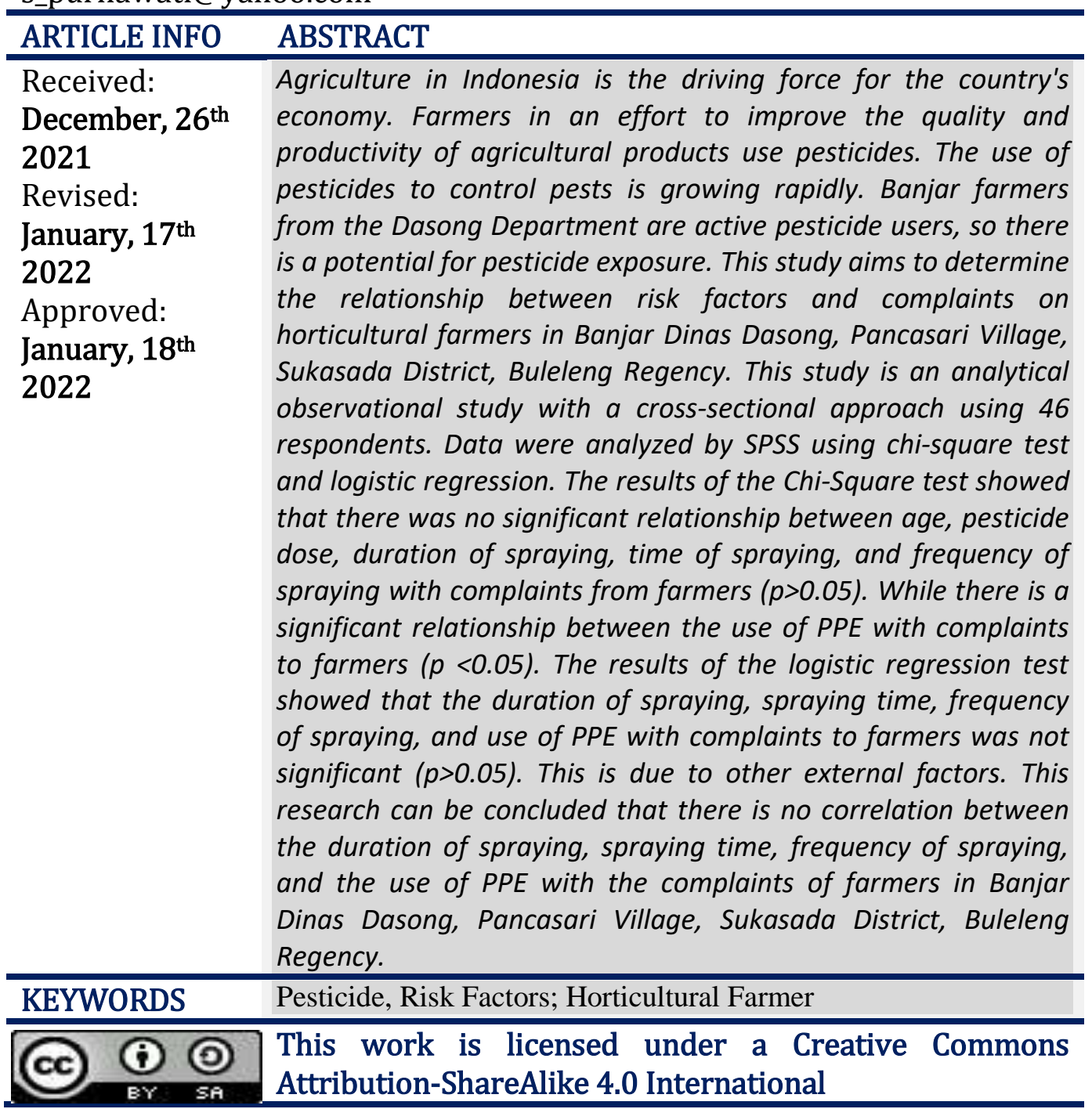

\begin{tabular}{ll}
\hline & Dewa Ayu Eka Wahyuni, I Made Muliarta, Susy Purnawati. (2022). \\
& Risk Factors Related to Pesticide Exposure in Banjar Horticultural \\
How to cite: & Farmers. Journal Eduvest. Vol 2(1): 14-21 \\
E-ISSN: & 2775-3727 \\
Published by: & https://greenpublisher.id/
\end{tabular}




\section{Dewa Ayu Eka Wahyuni, I Made Muliarta, Susy Purnawati}

\section{INTRODUCTION}

Agriculture in Indonesia has a very strategic role in the sector driving the country's economy. According to data (Central Statistics Agency, 2020) in February 2020 the number of workers in Indonesia was 137.91 million people. Employment that occupies the top rank is the agricultural sector with 38 million people (29.04\%). The data above shows that most districts in Indonesia still rely on the agricultural sector as a source of Regional Original Income. In the agricultural sector, there are several sub-sectors in it, such as horticulture, plantations, and food crops. Efforts to optimize the quality and productivity of agricultural products use various technologies, one of which is the use of pesticides (Kiloes \& Sulistyaningrum, 2019).

According to the Food and Agriculture Organization (FAO), a pesticide is any substance or mixture intended to prevent, destroy or control every pest, including vectors for humans or animal diseases, and unwanted plants or animals that causes damage during the production process. The use of pesticides in the agricultural sector in Indonesia is growing rapidly. Based on data from Agricultural Infrastructure and Facilities Statistics in 2016, the number of pesticide use was 3,930 people per year. Data from the World Health Organization (WHO) estimates that every year 1-5 million cases of pesticide poisoning occur in farmers with a mortality rate of 220,000 people.

Poisoning in Indonesia in the agricultural sector ranks second or third compared to other sectors (Tasmi, Lubis, \& Mahayuni, 2015). The prevalence of pesticide poisoning was obtained from moderate to severe levels. Farmers in Indonesia use a lot of organophosphate and carbamate pesticides which are synthetic pesticides (Wudianto, 2007). Farmers in Bali show the same thing, especially in Pancasari Village. Pancasari Village is one of the villages in Sukasada District, the majority of the population works in the agricultural sector. Pancasari Village is the largest agricultural center in Bali, especially in the horticulture sub-sector. The commodities cultivated in Pancasari Village are, strawberries, tomatoes, chilies, and peppers. Based on the results of water quality inspections in Lake Buyan, Pancasari Village, it was found that environmental pollution was caused by residues from organochlorine, organophosphate, and carbamate pesticides (Yadnyawati et al., 2020).

Organophosphate and carbamate pesticides have a way of working by inhibiting the enzyme acetylcholinesterase (AChE) through a phosphorylation process at the ester anion and synapses causing disorders of the autonomic nervous system. Inhibition of AChE causes accumulation of acetylcholine and binds to muscarinic and nicotinic receptors in the central and peripheral nervous systems. This buildup causes symptoms of poisoning that affect all parts of the body (Neal, 2020). Based on the complaints felt by farmers using pesticides, $60.9 \%$ of farmers showed specific complaints (Minaka, Sawitri, \& Wirawan, 2016).

Symptoms and signs of organophosphate and carbamate pesticide poisoning are often found with complaints of dizziness, nausea and increased fatigue. People are not aware and have the assumption that this does not require special attention (Puspitarani, 2016). Complaints felt by farmers can be influenced by internal and external factors. Insufficient information regarding exposure to organophosphate and carbamate pesticides on farmers. This study aims to determine the relationship between the variables of age, pesticide dose, duration of spraying, spraying frequency, and use of personal protective equipment with complaints to horticultural farmers who use pesticides in Banjar Dinas Dasong, Pancasari Village, Sukasada District, Buleleng Regency. 


\section{RESEARCH METHOD}

This research is an observational analytic study with a cross-sectional approach in which the independent variable and the dependent variable are observed at one time. This research was conducted in Banjar Dinas Dasong, Pancasari Village, Sukasada District, Buleleng Regency in June - September 2021. This study included 46 samples that met the inclusion criteria. The affordable population in this study were horticultural farmers who were exposed to organophosphate and carbamate pesticides in Banjar Dinas Dasong, Pancasari Village, Sukasada District, Buleleng Regency for the period June - September 2021.

The data collection technique used was purposive sampling method. This study used primary data obtained from interviews using a self-identity questionnaire and a pesticide exposure questionnaire. During the Covid-19 pandemic, the research was conducted door to door at farmers' homes and plantations. Researchers and respondents when collecting data in the field completely use PPE to prevent dangerous risks.

The independent variables in this study were age, pesticide dose, duration of spraying, time of spraying, frequency of spraying and use of PPE. While the dependent variable is farmers' complaints. Data were processed univariate, bivariate and multivariate with SPSS version 26. Bivariate analysis used chi-square test on categorical data. The independent variables in the bivariate analysis with $\mathrm{p}<0.25$ were included in the multivariate analysis. Multivariate analysis using logistic regression method. This study obtained an ethical clearance from the Research Ethics Commission of the Faculty of Medicine, Udayana University with the number 165/UN14.2.2.VII.14/LT/2021.

\section{A. Characteristics of Pesticide Use}

\section{RESULT AND DISCUSSION}

Table 1. Characteristics of Pesticide Use in Banjar Dinas Dasong

\begin{tabular}{llll}
\hline No. & Merek Dagang & Jenis & Golongan \\
\hline 1 & Acrobat & Fungisida & Morfolin \\
\hline 2 & Antracol & Insektisida & Karbamat \\
\hline 3 & Cabrio Top & Fungisida & Metoksi-karbamat \\
\hline 4 & Callicron & Insektisida & Organofosfat \\
\hline 5 & Curacron & Insektisida & Organofosfat \\
\hline 6 & Confidor & Insektisida & Neonikotinoid \\
\hline 7 & Daconil & Fungisida & Kloronitile \\
\hline 8 & Dursban & Insektisida & Organofosfat \\
\hline 10 & Decis & Insektisida & Poretroid dan Piretrin \\
\hline 11 & Demolish & Insektisida & Avermectin \\
\hline 12 & Endure & Insektisida & Spinosin \\
\hline 13 & Fra-re & Insektisida & Pirol \\
\hline 14 & Kanon & Insektisida & Organofosfat \\
\hline 15 & Sapporo & Fungisida & Inorganik \\
\hline 16 & Sidacron & Insektisida & Avermektin \\
\hline 17 & Sidazeb & Insektisida & Milbemisin \\
\hline
\end{tabular}


A total of 46 horticultural farmers in Banjar Dinas Dasong participated in this study. The use of pesticides on horticultural farmers in Banjar Dinas Dasong, Pancasari Village, Sukasada District, Buleleng Regency is listed in Table 1., indicating that the types of insecticides used by respondents, such as callicron, curacron, dursban, kanon, and sidacron brands. Fungicides used, such as morpholine, methoxy-carbamate, chloronitile, inorganic, and dithiocarbamate. Insecticides that are often used for spraying activities by horticultural farmers are organophosphates and carbamates.

\section{B. Characteristics of Horticultural Farmers' Risk Factors in Banjar Dinas Dasong} Table 2. Characteristics of Horticultural Farmers' Risk Factors in Banjar Dinas Dasong

\begin{tabular}{llc}
\hline Risk factors & Frequency & Percentage \\
\hline Age & 12 & \\
$<40$ & 34 & 26,1 \\
40 & & 73,9 \\
Pesticide Dosage & 5 & 10,9 \\
It is not in accordance with & 41 & 89,1 \\
In accordance & & \\
Spraying Time & 1 & 2,2 \\
$>4$ hours & 45 & 97,8 \\
4 hours & & \\
Spraying Time & 1 & 2,2 \\
Day dominant & 45 & 97,8 \\
Dominant morning/afternoon & & \\
Spraying frequency & 33 & 71,7 \\
$<1$ time/week & 13 & 28,3 \\
$>1$ time/week & & \\
Use of PPE & 30 & 65,2 \\
Incomplete $<5$ & 16 & 34,8 \\
Complete 5 & 46 & 100,0 \\
\hline Total & & \\
\hline
\end{tabular}

Based on the results of research conducted on 46 respondents, it is known that the distribution of risk factors is that the majority of farmers who carry out pesticide spraying activities are 40 years old as many as 34 people (73.9\%). The majority of farmers in Banjar Dinas Dasong have used the dosage according to the recommendations listed on the package, a total of 41 people $(89.1 \%)$. The dominant farmers spraying time 4 hours were 45 people $(97.8 \%)$, 45 people $(97.8 \%)$ were spraying in the morning or afternoon. Farmers mostly have a frequency of spraying less than 1 time per week as many as 33 people $(71.7 \%)$ and there are still many farmers who use incomplete PPE $<5$ as many as 30 people $(65.2 \%)$. A small number of farmers, amounting to 9 people (19.6\%) felt complaints after carrying out pesticide spraying activities. The types of complaints that are felt include headaches, increased fatigue, itching, and nausea.

Cross Tabulation and Chi-Square . Significance Test

Table 3. Cross Tabulation and Chi-Square Significance Test for Risk Factors with Complaints

\begin{tabular}{cccccc}
\hline \multirow{2}{*}{ No Variabel } & \multicolumn{2}{l}{ Farmer's Complaint } & & & \\
\cline { 2 - 5 } & Ada & $\%$ & Tidak & $\%$ & \\
\hline
\end{tabular}




\begin{tabular}{|c|c|c|c|c|c|c|}
\hline \multirow[b]{2}{*}{1} & \multirow[b]{2}{*}{ Age } & \multicolumn{4}{|c|}{ ada } & \\
\hline & & & & & & \multirow{3}{*}{0,409} \\
\hline & 40 years & 8 & 23,5 & 26 & 76,5 & \\
\hline & $<40$ years old & 1 & 8,3 & 11 & 91,7 & \\
\hline \multirow[t]{3}{*}{2} & Pesticide Dosage & & & & & \\
\hline & $\begin{array}{l}\text { It is not in accordance } \\
\text { with }\end{array}$ & 1 & 20,0 & 4 & 80,0 & \multirow[t]{2}{*}{1,000} \\
\hline & In accordance & 8 & 19,5 & 33 & 80,5 & \\
\hline \multirow[t]{3}{*}{3} & Spraying Time & & & & & \multirow{3}{*}{$0,196^{+}$} \\
\hline & $>4$ hours & 1 & 100 & 0 & 0,0 & \\
\hline & 4 hours & 8 & 17,8 & 37 & 82,2 & \\
\hline \multirow[t]{3}{*}{4} & Spraying Time & & & & & \\
\hline & Day dominant & 1 & 100 & 0 & 0,0 & \multirow[b]{2}{*}{$0,196^{+}$} \\
\hline & $\begin{array}{l}\text { Dominant } \\
\text { morning/afternoon }\end{array}$ & 8 & 17,8 & 37 & 82,2 & \\
\hline \multirow[t]{3}{*}{5} & Spraying Frequency & & & & & \multirow{3}{*}{$0,092^{+}$} \\
\hline & $\begin{array}{l}\text { More than } 1 \\
\text { time/week }\end{array}$ & 5 & 38,5 & 8 & 61,5 & \\
\hline & Less than 1 time/week & 4 & 12,1 & 29 & 87,9 & \\
\hline \multirow[t]{3}{*}{6} & Use of PPE & & & & & \\
\hline & Incomplete $<5$ & 9 & 30,3 & 21 & 70,0 & \multirow{2}{*}{$0,018^{*^{+}}$} \\
\hline & Complete 5 & 0 & 0,0 & 16 & 100 & \\
\hline
\end{tabular}

The results of the chi-square analysis to see the relationship between the independent variable and the dependent variable. Based on Table 3, it shows that there is no significant relationship between age, pesticide dose, duration of spraying, time of spraying and frequency of spraying with farmer complaints ( $p>0.05)$. However, other risk factors such as the use of PPE have a significant relationship with farmer complaints after spraying activities $(\mathrm{p}<0.05)$.

\section{Logistics Regression Multivariate Analysis}

Table 4. Results of Multivariate Logistics Regression Analysis

\begin{tabular}{|c|c|c|c|c|}
\hline Variabel & $\begin{array}{l}\text { Pseudo } \\
\text { R-Square } \\
\end{array}$ & $\begin{array}{l}\text { Koefisien } \\
\text { Regresi (B) } \\
\end{array}$ & OR (Exp. B) & $\begin{array}{l}\mathrm{P} \\
\text { value }\end{array}$ \\
\hline Spraying Time & & 22,877 & 96986158662 & 1,000 \\
\hline Spraying Time & 0,481 & 21,426 & $59 \quad 20193431$ & 1,000 \\
\hline Spraying Frequency & & 1,451 & 4,267 & 0,115 \\
\hline Use of PPE & & 19,953 & $9,6^{26305255}$ & 0,998 \\
\hline constant & & $-44,080$ & 0,000 & 0,999 \\
\hline
\end{tabular}

Multivariate analysis used binary logistic regression method with independent variables in bivariate analysis with $\mathrm{p}<0.25$. Variables such as duration of spraying, time of spraying, frequency of spraying, and use of PPE were analyzed simultaneously. The results of the multivariate analysis are presented in the form of Table 4, it is known that the pseudo R-Square value obtained through the logistic regression test is 0.481 or $48.1 \%$ 


\section{Dewa Ayu Eka Wahyuni, I Made Muliarta, Susy Purnawati}

(Nagelkerke). Based on these results, it indicates that the variables of spraying time, spraying time, frequency of spraying, and the use of PPE to explain complaints to farmers are $48.1 \%$, of which $51.9 \%$ are explained by external factors.

Table 4 shows that the duration of spraying, time of spraying, frequency of spraying, and use of PPE have no effect on farmer complaints because this multivariate analysis will compete with other variables.

\section{Discussion}

This study shows that from a total of 46 respondents, 9 (19.6\%) horticultural farmers from Banjar Dinas Dasong had specific complaints due to pesticide poisoning. Research conducted on farmers in Gondosuli, Central Java by $93.8 \%$, farmers in Jember by $60 \%$ found specific complaints due to pesticides (Rahmasari \& Musfirah, 2020). The difference in the results was caused by the sampling technique and the instrument used.

The results of the bivariate analysis showed that there was no significant relationship between age and farmer complaints $(p=0.409)$. This study is in line with previous research conducted on farmers in Karo Regency which found no relationship between age and health complaints. The results of this study are supported by Ipmawati's research, spraying activities are classified as productive age, capable, and ready to increase income to the maximum (Ipmawati, Setiani, \& Darundiati, 2016)

There was no significant relationship between pesticide doses and farmers' complaints $(\mathrm{p}=1,000)$. These results are in line with research conducted in Pancasari Village which found no significant relationship between pesticide doses and farmers' health complaints (Minaka et al., 2016). The results of this study are not in accordance with the theory. Because the larger the dose used, the risk of pesticide poisoning will increase. This discrepancy in results is caused by farmers carrying out spraying activities on land that is not too large and the exposure time is not long (Mardiyah et al, 2019).

The risk factor for spraying time did not have a significant relationship with farmers' complaints $(\mathrm{p}=0.196)$. These results are in accordance with research in Tejosari Village, it is known that there is no significant relationship between the duration of spraying and the health complaints of farmers (Runia, 1993). These results are in line with previous research in Balik Bukit District, West Lampung Regency, which found that there was no relationship between the duration of spraying and the health complaints of farmers (Yushananta, Melinda, Mahendra, Ahyanti, \& Anggraini, 2020). According to the Minister of Manpower Regulation No. Per-03/Men/1986, it is stated that you should not be exposed to pesticides more than 5 hours a day and 20 hours a week in order to avoid unwanted effects.

This study stated that there was no relationship between the time of spraying and the complaints felt by farmers $(p=0.196)$. This research is in line with research conducted in Canada which states that farmers carry out spraying activities in the morning or evening (Maybank, Yoshida, \& Grover, 1978). The study in Mendongan Village, Sumowono District, Semarang Regency obtained the same results showing that there was no significant relationship between spraying time and cholinesterase levels (Pradananingrum, Setyaningsih, \& Suwondo, 2021). The time of applying pesticides will determine the effectiveness of the pesticides that are sprayed. If the time of spraying is done properly, then pest control will be optimal.

Spraying frequency did not have a significant relationship with farmers' complaints $(\mathrm{p}=0.092)$. These results are similar to research conducted in Candi Village, Bandungan District, which showed that there was no significant relationship between spraying frequency and farmer complaints. The more often farmers carry out spraying 
activities, the higher the risk of poisoning due to pesticides. So that the level of the enzyme cholinesterase decreases. The frequency of spraying should be carried out according to the established rules, a maximum of 2 times a week (Samosir et al, 2017). In fact, farmers carry out spraying activities according to the needs in the field. If plants are attacked by pests, farmers will spray more often without paying attention to the rules that have been set.

The use of PPE has a significant relationship with farmers' complaints ( $\mathrm{p}=0.018$ ). Research in Gondosuli Magelang Village is in accordance with this study, where a significant relationship was found between the use of PPE and farmer complaints (Rahmasari \& Musfirah, 2020). A similar study conducted in Rurukan Regency showed the results $(\mathrm{p}=0.002)$ that there was a relationship between the use of PPE and cholinesterase enzymes (Tutu, Manapiring, \& Umboh, 2020).

The results of the multivariate analysis showed different results on the use of PPE, the p-value was 0.998 , meaning that there was no significant relationship between the use of PPE and the complaints felt by farmers in Banjar Dinas Dasong, Pancasari Village, Sukasada District, Buleleng Regency. This causes there to be no significant relationship between these two variables, such as the number of samples, the lack of instruments, and the sampling technique used.

Farmers feel unfamiliar and uncomfortable when they have to use full PPE. The majority of farmers who spray pesticides only use long clothes, head coverings, and boots. Based on the theory, the use of PPE when spraying activities will protect farmers in the area from direct exposure to pesticides. The risk of poisoning will be reduced if used completely. According to (Ministry of Health of the Republic of Indonesia, 2016) the recommended PPE for farmers who spray pesticides is obliged to use (1) head protection in the form of a hat/helmet; (2) eye and face protection in the form of goggle glass/face shield; (3) respiratory protection in the form of masks; (4) latex gloves/handscoons; (5) protective clothing in the form of long-sleeved shirts and longsleeved pants; (6) gaiters/boots.

Based on the results of interviews, respondents stated that most of them did not use complete PPE because they were used to and uncomfortable when spraying. Most farmers do not use PPE in the form of masks and gloves. Pesticide contamination that ranks first occurs through the skin. Poisoning due to pesticide particles entering through inhalation ranks second. If farmers do not use PPE completely, it will make pesticides easy to absorb into the body.

Organophosphate pesticides are very dangerous because the pesticide and cholinesterase bonds are irreversible. Other health impacts that will result from long-term use of organophosphate pesticides, such as neurobehavioral or neurotoxic symptoms. Interaction with other enzymes can occur in some organophosphates called esterase target neuropathy (NTE) which is found in the brain and spinal cord (Dhamayanti \& Saftarina, 2018).

\section{CONCLUSION}

Based on the results of bivariate analysis, the risk factor for the use of PPE has a significant relationship with farmer complaints $(\mathrm{p}=0.018)$. In multivariate analysis, it was found that risk factors, such as duration of spraying, time of spraying, frequency of spraying and use of PPE had no effect on farmer complaints ( $p>0.05$ ).

Suggestions to farmers during spraying activities should use complete PPE to minimize direct exposure to pesticides. Further research can be done to examine the poisoning of farmers to determine blood cholinesterase levels using the Tintometer Kit. 


\section{Dewa Ayu Eka Wahyuni, I Made Muliarta, Susy Purnawati}

\section{REFERENCES}

Ipmawati, P. A., Setiani, O., \& Darundiati, Y. H. (2016). Analysis of Risk Factors Affecting the Level of Poisoning Poisoning in Farmers in Jati Village. Kesehat Masy, 4(1), 427-435.

Kiloes, A. M., \& Sulistyaningrum, A. (2019). Farmer's behavior in using pesticides on shallots cultivation in Solok Highlands, West Sumatera. IOP Conference Series: Earth and Environmental Science, 399(1), 12116. IOP Publishing.

Maybank, J., Yoshida, K., \& Grover, R. (1978). Spray drift from agricultural pesticide applications [Canada]. Journal of the Air Pollution Control Association (USA).

Minaka, IADA, Sawitri, Anak Agung Sagung, \& Wirawan, Dewa Nyoman. (2016). Hubungan penggunaan pestisida dan alat pelindung diri dengan keluhan kesehatan pada petani hortikultura di buleleng, bali. Public Health and Preventive Medicine Archive, 4(1), 94-103.

Neal, Michael J. (2020). Medical pharmacology at a glance. John Wiley \& Sons.

Pradananingrum, Sinta, Setyaningsih, Yuliani, \& Suwondo, Ari. (2021). Karakteristik Individu, Prosedur Penyemprotan dan Tingkat Cholinesterase: Studi Literatur pada Pekerja yang Terpapar Pestisida. Jurnal Ilmiah Permas: Jurnal Ilmiah STIKES Kendal, 11(2), 283-290.

Puspitarani, Dwi. (2016). Gambaran Perilaku Penggunaan Pestisida Dan Gejala Keracunan Yang Ditimbulkan Pada Petani Penyemprot Sayur Di Desa Sidomukti Kecamatan Bandungan Kabupaten Semarang. Universitas Negeri Semarang.

Rahmasari, Dani Aulia, \& Musfirah, Musfirah. (2020). FAKTOR YANG BERHUBUNGAN DENGAN KELUHAN KESEHATAN SUBJEKTIF PETANI AKIBAT PENGGUNAAN PESTISIDA DI GONDOSULI, JAWA TENGAH. Jurnal Nasional Ilmu Kesehatan, 3(1), 14-28.

Runia, David T. (1993). Philo in early Christian literature: A survey (Vol. 3). Uitgeverij Van Gorcum.

Tasmi, Daniel, Lubis, Halinda Sari, \& Mahayuni, E. L. (2015). Hubungan Status Gizi dan Asupan Energi Dengan Kelelahan Kerja pada Pekerja di PT. Perkebunan Nusantara I Pabrik Kelapa Sawit Pulau Tiga Tahun 2015. Jurnal Lingkungan Dan Kesehatan Kerja, 4(2), 22-27.

Tutu, Christien Gloria, Manapiring, Aaltje Ellen, \& Umboh, Adrian. (2020). FaktorFaktor Yang Berhubungan Dengan Aktivitas Enzim Cholinesterase Darah Pada Petani Penyemprot Pestisida. Indonesian Journal of Public Health and Community Medicine, 1(4), 40-53.

Wudianto, R. (2007). Petunjuk Penggunaan Pestida. Penerbit Penebar Swadaya. Jakarta.

Yadnyawati, Ida Ayu Gde, Ardhana, I. Ketut, Rohmana, Muhammad Saifullah, Swandi, I. Wayan, Wibawa, Arya Pageh, Julianto, I. Nyoman Larry, Marsiyanti, Dwi Any, Sunartha, I. Gusti Made, Purnamaningsih, Ida Ayu Made, \& Ruastiti, Ni Made. (2020). COMMUNITY, ECOLOGY, AND RELIGION Interdisciplinary and civic engagement towards sustainable living. Unhi Press.

Yushananta, Prayudhy, Melinda, Nia, Mahendra, Arif, Ahyanti, Mei, \& Anggraini, Yetti. (2020). Faktor Risiko Keracunan Pestisida Pada Petani Hortikultura di Kabupaten Lampung Barat. Ruwa Jurai: Jurnal Kesehatan Lingkungan, 14(1), 1-8. 